\title{
IAMJ
}

INTERNATIONAL AYURVEDIC MEDICAL JOURNAL

\section{ETIOPATHOGENESIS OF KUSHTHA - A CONCEPTUAL STUDY}

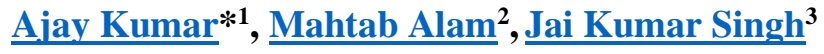 \\ ${ }^{* 1,2}$ Post Graduate Scholar, Agada Tantra Evam Vidhi Vaidyaka \\ ${ }^{3}$ Professor \& H.O.D, Agada Tantra Evam Vidhi Vaidyaka Government Ayurvedic College, \\ Patna, Bihar, India
}

\section{Corresponding Author: ajeyara02@gmail.com}

\section{https://doi.org/10.46607/iamj1 1 p5062021}

(Published online: September 2021)

Open Access

(C) International Ayurvedic Medical Journal, India 2021

Article Received: 12/08/2021 - Peer Reviewed: 30/08/2021 - Accepted for Publication: 31/08/2021

\section{Check for updates}

\begin{abstract}
Ayurveda has mentioned all skin illnesses under the name of Kushtha, and in different words, it could be known as "Ayurveda Dermatology". Kushtha is especially divided into seven types of Maha Kushtha and 11 types of Kshudra Kushtha. Generally, differential diagnosis and identification of a selected Kushtha may be very difficult as there aren't any clear tools or no images provided in authentic Ayurveda texts and it is also very difficult to understand the pathogenicity hence, to overcome this problem, a deep study of literature on skin illnesses was performed in this article in titles of Aetiology, As a Sankramaka Roga and Hereditary incidence.
\end{abstract}

Keywords: Kushtha, Aetiology, Sankramaka Roga, Hereditary incidence, Dhatus

\section{INTRODUCTION}

Kushtha is one of the most baneful diseases afflicting man. Ayurveda has dealt with the disease in all its aspects elaborately. The description of the Lakshana of the different varieties in accordance with the doshic predominance as also the involvement of the dhatus is exhaustive. Certain common aspects of some of the important varieties of Maha Kushtha are dealt with in this paper, restricting to practical and clinical aspects rather than elaborating the textual version. The Disease is more prevalent in tropical countries and appears particularly in areas where human contact is close and continuous in unhygienic conditions over a 
prolonged period. The onset of the disease is very insidious and is characterised by a chronic and protracted course, generally culminating in disintegration and eventual destruction of tissues. The causes of Kushtha with special references to Papa karmas and the part played by an external factor like Krimi are discussed in this study.

\section{Literature Review}

1. Aetiology: Incompatible articles of diet (Viruddha Ahara) indulging persistently for a long time, suppression or provocation of the natural physiological functioning of the system (Vegas) and other irregularities in diet and recreation (Mithya Aharavihara) in subjects whose mental disposition is of a sinful nature (Papa Karma) produce a severe type of dosha vaishamya of all the three doshas which predisposes the subject to this dreadful disease. It is one of the $M a$ harogas and is not amenable to treatment in the later stages when all the dhatus are involved. If the above causes are in operation for a long and continuous period the Twak, Lasika, Mamsa and Rakta are vitiated by the doshas depending on the Roga Marga and initial signs and symptoms in the form of skin lesions develop. The course of the disease is very slow but progressive. The Dhatus, Rasa (Twak) Rakta. Mamsa, Medas, Asthi Majja \& Shukra get spoilt gradually during the process of Dhatuparinama. Eventually, the unhealthy dhatus begin to disintegrate by the Kleda \& tissue destruction sets in due to Kotham when all the dhatus are affected. The mental set-up of the individual as mentioned above is a very important factor to be reckoned with. Commission of sinful deeds and heinous actions (Papa karmas) is a contributory cause. This points to the possibility that people of Rajasika Prakrithi-emotional type are more prone to be the victims. Further in the matter of treatment also, stress on the necessity for rectification of Manasikadoshas by way of purification of thoughts, words and deeds besides the proper management of Sharirika Doshas is implied.

2. As a Sankramaka Roga: The vitiated doshas gain entry into the blood vessel (Siras) and spoil the Twak, Rakta and Mansa Dhatus, the effect of the dosha Vaishamya is so severe that these dhatus in course of
Time lose their vitality and being to disintegrate due to excess of Kleda. Clinically, Skin manifestations such as patches of discolouration with loss of sensation or hypersensitivity, dryness or softness, lack of sweda or excess of sweda, itching and other typical signs are noticed at this stage. Gradual and progressive deterioration of the tissues sets in and destruction of Roma. Twak, snayu, Dhamani and Tarunasthi takes place due to the development of Krimi. The Krimis of an infected individual can produce the disease in an otherwise healthy person by invasion through a breach of the surface by prolonged contact or very close association. Where the affliction of the disease is by contagion the dhatu vitiation takes place directly and dosha vaishamya sets in as a consequence. The Raktaja Krimis are the ones that have the power to eat away the tissues. They have an affinity for Rakta and Mamsa and readily invade the open wounds of those in close contact with the infected person. They are:

Among these six varieties, some are so infinitesimally small that they are not perceptible to the naked eye. Others are visible round and copper coloured. The modern concept of the cause of Leprosy is by infection with Mycobacterium Leprae or Hansen's Bacillus. Examination of the skin scraping, or Nasal Scraping reveals the presence of the bacillus in Lepromatous Leprosy. In tuberculoid type, the scrapings do not always show the bacillus. In such cases, the diagnosis is made merely in clinical findings. The nerve biopsy reveals the presence of bacillus in some cases.

\section{Hereditary incidence}

According to Ayurveda, the offspring of the people affected with Kushta contract the disease through affected Shukra or shonitha. The Allopathic system does not lend any support to this theory.

\section{Varieties}

Ayurveda describes 18 varieties of Kushtha-7 Mahakushthas and 11 Kshudra Kushtha. The Mahakushthas being the more serious varieties are taken up for a critical study in this paper. The preponderance of the doshas determines the variety of Kushtha and is based on the dosha Lakshana. The dhatus involved determine the course and termination of the disease. Hence a judicious study of both the Lakshanas of factors is 
essential for diagnosis and treatment. The different varieties of Kushtha are not given here, as it will be only a repetition of the textual version.

The appearance of skin changes is the first sign of the disease in a majority of cases. The earliest changes are difficult to differentiate but as they develop slowly over months the difference both in reference to doshas and dhatus become more obvious.

The Involvement of the Dhatus: The gravity of the disease is due to the fact that the tridosha and Sapta dhatus are affected. The involvement of the deeper dhatus takes place gradually which account for the slow, sure and stealthy progress of the condition. The Lakshanas when the dosha-vitiation is primarily seated in each of the dhatus are given hereunder

Rasa dhatu (Twak): Discolouration (Vaivarnya), dryness (Ruksha) Loss of sensation (Supti) excessive perspiration (Athisweda).

Rakta: Itching (Kandu) inflammation and suppuration (Vipooyaka).

Mansa: Large thick and Indurated patches -(Bahula) fissures and cracks (Sphotam) dryness of the mouth (Vaktrashosha), rough skin nodules-Pitaka, pain (Thoda).

Medas: The foregoing Lakshanas and gradual loss of function of the affected area.

Asthi and Majja: Destruction of nasal bones, eye affection, throat affection, development of Krimi, destruction of tissues. With the involvement of the deeper dhatus the lakshanas manifested by the affection of the former dhatus will also be present.

Shukra: The spoilt Shukra \& Shonita transmits the disease to the offspring.

According to Allopathy: The disease is classified under two principal varieties, the lepromatous \& the tuberculoid caused by the invasion of Mycobacterium Leprae, with many varieties of intermediate development Lepromatous Leprosy develops in a patient with little resistance to the organism. The skin first sign of the infection is the appearance of a flushed shiny macule in the skin. This thickens and becomes oedematous especially in the supraorbital, frontal and malar prominences and ear lobes. They become necrotic and ulcerate. Constitutional symptoms are also noticed.
Tuberculoid Leprosy: The skin lesions are sharply defined, infiltrated and raised above the skin surface. The skin is dry, hairless, Scaly, and frequently depigmented. The area is analgesic and anaesthetic, small nerves are thickened and may be palpable. The nerve trunks are involved, and destruction of the fibres leads to motor and sensory changes in the relevant areas and Deformity develops. Damage to the tissues and perforating ulcers may develop. Involvement of the nerves leads to loss of sensation and interference with movement.

It may be noticed that Mahakushthas like Kapala. Udumbara and Mandala Kushta affecting the Twak, Rakta, Mamsa \& Medas conform to the signs and symptoms of Tuberculoid type and Those seated in all the dhatus including Asthi and Majja come under Lepromatous Leprosy.

\section{CONCLUSION}

The entire body becomes mutilated and makes the appearance of the person ugly is called Kushtha. The eighteenth form of Kushtha is defined and these are again subdivided into Maha Kushtha \& Kshudra Kushtha. Sushruta was the first person who described that Kushtha as a result of one or more abnormalities in the genome, particularly a condition that is present from birth (congenital) and it's far passed down from the mother and father's genes. He additionally defined that Krimi is one of the causative components of Kushtha. Development of Kushtha at tissue level changed into actually stated. Kushtha develops because of incompatible dietetic and unusual activities. It will be seen from the above that a close study of the individual Lakshanas of Kushtha with their effect on the dhatus is essential for arriving at the correct diagnosis and for chalking out the line of treatment.

\section{REFERENCE}

1. Agnivesha, Charaka Samhita with Ayurveda Dipika Commentary edited by Vaidya Yadavji Trikamji Acharya, Chaukhambha Orientalia, Varanasi-2007.

2. Sharma Priyabrata, Sushrutha Samhita, Reprint. Varanasi: Chaukhamba Visvabharati;2005.

3. Murthy $K R$; Asthanga Sangraha, Varanasi; Chaukhamba Sanskrit Samsthan. 
4. Sharma Ram Karan, Dash Bhagwan. Charaka Samhita with Ayurveda Dipika Commentary. Varanasi; Chaukhamba Krishnadas Academy.

5. Murthy K R; Astanga Hridaya, $I^{\text {st }}$ ed Chaukhambha Orientalia Varanasi.

6. Murthy Srikanth K.R., Astanga Hridaya, $1^{\text {st }}$ ed. Varanasi; Chaukhamba Sanskrit Series.

7. Sharma Priyavrat, Susrutha Samhita, Reprint. Varanasi: Chaukhamba Visvabharati;2005.

8. Murthy KR; Astanga Hridaya, Varanasi; Chaukhamba Sanskrita Samsthana

9. Dalhana Acharya, Sushruta Samhita with Nibandhasangrha Commentary Edited by Vaidya Yadavji Trikamji Acharya, Chaukhambha Surbharti Prakashan Varansi 2012.

10. Shastri Ambika Dutta Susruta Samhita Edited with Ayurveda-Tattva-Sandipika. Chaukhambha Sanskrit Sansthan, Varanasi 2015.

11. Gharami, Ramesh Chandra, Clinical Dermatology, New Central Agency Book (p)Ltd 8/1 Chintamani Das Lane, Kolkata.2007 pg 26, 211-224

12. Pasricha J. S. \& Gupta Ramji, Illustrated Textbook of Dermatology, Jaypee brothers' medical publishers (p) Ltd, Daryaganj, New Delhi 1999.pg-38-40

\section{Source of Support: Nil \\ Conflict of Interest: None Declared}

How to cite this URL: Ajay Kumar et al: Etiopathogenesis Of Kushtha - A Conceptual Study. International Ayurvedic Medical Journal \{online\} 2021 \{cited September 2021\} Available from: http://www.iamj.in/posts/images/upload/3118 3121.pdf 